\title{
The Rediscovery of 'Noel's Special' Passion Fruit
}

\section{Francis Zee $^{\mathbf{1}}$ and Mark Munekat ${ }^{2}$}

U.S. Department of Agriculture, Agricultural Research Service, National Clonal Germplasm Repository, Hilo, HI 96720

\section{Philip Ito ${ }^{3}$}

Department of Horticulture, University of Hawaii, Honolulu, HI 96822

Additional index words. germplasm, juice, tropical

'Noel's Special', a vegetatively propagated yellow passion fruit (Passiflora edulis Sims $\mathrm{f}$. flavicarpa) with unusually bright orangecolored juice and tolerance to alternaria brown spot (Alternaria passiflorae Simmons) was released in 1978 (Ito, 1978).

The original 'Noel's Special' was selected in 1968 from open-pollinated seedlings of a single plant grown in an abandoned farm in Hilo, Hawaii. According to Ito (1978), 'Noel's Special' produces $\leq 88 \%$ marketable fruit in a single season. Fruit were round and yellow and weighed between 56 to $102 \mathrm{~g}$. The pulp color was deep orange, with $43 \%$ to $56 \%$ juice recovery; total soluble solids concentration (SSC) ranged between $15.0 \%$ to $19.8 \%$. The selection was named after Noel Fujimoto, a deceased graduate student who brought attention to the original plant (Ito, 1978). However, 'Noel's Special' was lost for $>10$ years.

\section{Origin}

In Dec. 1993, cuttings and three fruit were collected from a vine in the backyard of Philip and Barbara Williams of Puueopaku, Hawaii, and designated as N94-18. Eight cuttings of N94-18 were rooted and field-planted in May 1994 in two plots at the U.S. Dept. of Agriculture, Agricultural Research Service (USDAARS), National Clonal Germplasm Repository, located at the Univ. of Hawaii, Waiakea Agriculture Experiment Station, Hilo. The station is $9.7 \mathrm{~km}$ outside of Hilo, with an elevation ranging from 175 to $227 \mathrm{~m}$. Mean air maxima and minima were 28 and $16 \mathrm{C}$. Annual

Received for publication 2 Feb. 1995. Accepted for publication 26 Apr. 1995. Use of trade names does not imply endorsement of the products named or criticism of similar ones not named. The cost of publishing this paper was defrayed in part by the payment of page charges. Under postal regulations, this paper therefore must be hereby marked advertisement solely to indicate this fact.

${ }^{1}$ Curator. Current address: U.S. Dept. of Agriculture, Agricultural Research Service, P.O. Box 4487, Hilo, HI 96720.

${ }^{2}$ Research Technician.

${ }^{3}$ Horticulturist. Current address: Beaumont Agricultural Research Center, Hilo, HI 96720. rainfall averaged $4445 \mathrm{~mm}$ and was most abundant during October to February. The soil consisted of an extremely stony Papai muck, with organic soils formed over mostly fragmental a'a lava (U.S. Soil Conservation Service, 1985).

A small crop was harvested from these vines during Oct. 1994 to Jan. 1995. Between 1 Oct. and 11 Dec. 1994, we recorded 1731 $\mathrm{mm}$ of precipitation.

\section{Description}

Fifty randomly harvested fruit were examined between 7 Dec. 1994 to 18 Jan. 1995. Fruit were oval, with average length and width at 6.1 and $5.5 \mathrm{~cm}$, respectively (Fig. 1). Mature fruit were orange-yellow; average Hunter $\mathrm{L}^{*}$ (value), $\mathrm{a}^{*}$ (hue), and $\mathrm{b}^{*}$ (chroma) readings were $69.89,7.44$, and 61.14 , respectively (modelCR-200; Minolta chromameter, Osaka, Japan). Fruit weight ranged from 56 to $160 \mathrm{~g}$ and averaged $119 \mathrm{~g}$. Juice recovery was as high as $47 \%$ and averaged $39 \%$. Juice was
Fig. 1. 'Noel's Special' (N94-18) passion fruit. bright orange, with average $\mathrm{L}^{*}, \mathrm{a}^{*}, \mathrm{~b}^{*}$ values of $42.66,11.46$, and 30.7 , respectively. Total SSC ranged between $13 \%$ to $15.5 \%$ and averaged $14.4 \%$. Total acidity averaged $2.61 \%$. The extracted juice retained a bright-orange color, even after being frozen and thawed.

Alternaria and anthracnose fruit spots were present on some mature fruit, and many of the fruitlets that set during the extremely wet period dropped. In addition to the high rainfall, Waiakea station is also a severe infestation zone of the oriental fruit fly (Dacus dosalis Hendel). N94-18 fruit showed none to mild fruit fly damage. Some fruit had slight to moderate ovipositing scars and slight distortions. The pulp quality was not affected.

As with most $P$. edulis f.flavicarpa, N9418 is self-incompatible and needs pollination from other vines to set fruit. It should be interplanted with passion fruit seedlings or other clones to ensure cross-pollination.

N94-18 is released as 'Noel's Special', because the fruit characteristics are almost identical to those published earlier (Ito, 1978).

\section{Availability}

Limited quantities of 'Noel's Special' cuttings are available through the USDA-ARS, National Clonal Germplasm Repository-Hilo, P.O. Box 4487, Hilo, HI 96720. The materials have not been tested for viruses or other diseases.

\section{Literature Cited}

Ito, P.J. 1978. 'Noel's Special' passion fruit. HortScience 13:197.

U.S. Soil Conservation Service. 1985. Soil survey report of Waiakea Experimental Farm, Univ. of Hawaii. U.S. Soil Conservation Service, Hilo.



